\title{
The FDI of Small- and Middle-Sized Enterprises: A Literature Review
}

\author{
Hualin Pu, Yongdan Zheng \\ Department of International Economics and Trade, College of Economics, Jinan University, Guangzhou, China \\ Email: georgepu@sina.com, zhengyongdan@foxmail.com
}

Received 22 January 2015; accepted 13 February 2015; published 16 February 2015

Copyright $@ 2015$ by authors and Scientific Research Publishing Inc.

This work is licensed under the Creative Commons Attribution International License (CC BY). http://creativecommons.org/licenses/by/4.0/

(c) (i) Open Access

\begin{abstract}
In recent years, increasing SMEs (small- and middle-sized enterprises) started internationalization, and FDI became an important approach for SMEs to participate in international activities. As traditional FDI theories explain little about the FDI activities of small and medium companies, the paper reviews the related literatures about the FDI of SME, classifies the motives of conducting FDI, elaborates the decision-making process, concludes the investment performance and summarizes the related empirical studies and the defects of existing literature.
\end{abstract}

\section{Keywords}

Small- and Middle-Sized Enterprises, FDI

\section{Introduction}

In terms of FDI theory, we need to explain the two issues of "why" and "how". The traditional theories explained that "why" mainly includes the monopolistic advantage theory based on imperfect competition proposed by Hymer [1], the product life cycle theory proposed and developed by Vernon [2], the trade and investment theory based on marginal comparative advantage proposed by Kojima [3], internalization theory based on transaction cost proposed by Buckley and Casson [4], and the internalization theory based on OLI-Model proposed by Dunning [5] [6]. The traditional theories explained that "how" mainly includes the vertical and horizontal FDI theory based on industrial organization proposed by Caves [7], and the innovation model proposed by Johanson and Vahlne [8] [9].

However, these theories and models explain little about the FDI of small and medium enterprises for the two reasons: first, they contain an implicit assumption that the study object is large enterprise; second, SME lack of the advantages in product and technology development, financing, human resources, information acquisition, management experience, marketing strategy and risk tolerance. SMEs, knowledge-extensive SMEs in particular, 
do not strictly follow the traditional stage model, but featured with "leap frog”. Moreover, the conceptions of “Born Global” and "International New Ventures” proposed by Knight [10] and McDougall and Oviatt [11] challenged traditional FDI theory. Traditional theories might vaguely explained the motives and modes of SME's FDI, but some modern theories proposed by Buckley, Liesch and Knight, Hollenstein provided some new perspectives and made up the deficiency [12]-[14].

In accordance with the traditional theory, the representative SME theory also needs to explain the two issues of "why" and "how".

\section{Theories about the Motives of SMEs Conducting FDI}

\subsection{Small-Scale Technology Theory}

In accordance with Small-Scale Technology Theory by Wells [15], the enterprises in small-scale markets like developing countries are featured with higher flexibility and lower technology costs, which enable them to capture the market with a faster speed and a lower price. In comparison to SMEs, the multinationals respond slower since the scale effect usually acquires longer time.

\subsection{Entrepreneurship Theory and International New Ventures}

Rennie, McDougall and Oviatt proposed International Entrepreneurship Theory. It argues that SME's internationalization mostly attributes to entrepreneur's international vision and international experience, their internationalization development is either proactive or reactive [11] [16] [17]. McDougall and Oviatt define general international entrepreneurship as "a set of behaviors conducted by commercial organization in order to accomplish the goal of organization value creation, including creativity, initiative and risk taking moves [18].” Scholars often combine Entrepreneurship theory and International New Ventures together to explain the internationalization behaviors of the younger and smaller companies.

According to McDougall and Oviatt, while other competitors start internationalization long after establishment, few new ventures follow the conventional market entry procedures [18]. Thus, new ventures could utilize learning abilities to achieve rapid growth in host countries. McDougall and Oviatt mentioned that most new ventures are founded by entrepreneurs with international experience and international market prospective [11]. Their education background, work experience and personal thoughts play a decisive role in the company's internationalization development. Knight concludes that better enterprises have stronger tendency to change marketing strategies when entering new markets, and in SMEs, entrepreneurship have more profound influence on enterprise's globalization process [19].

\subsection{International Stage Theory}

Uppsala model is the core of international stage theory, it divides the internationalization of enterprises into four stages: no regular export activities, export via independent representatives, establishment of sales subsidiary, production or manufacturing. International stage theory explains enterprises' internationalization without regard of size and scale, After the empirical analysis, Bilkey, Johansson and Nonaka found that SMEs' internationalization showed significant periodicity in operating activities [20] [21]. Yip and Biscarri analyzed the newly internationalizing firms, which do not follow a systemic approach, but the following six steps: Motivation and strategic planning, market research, market selection, entry mode selection, infrequent events and issues of planning, strategy and investment of resources supplement [22].

\section{Theories about Decision-Making Process and Approach}

\subsection{Network Theory and Social Capital Theory}

Johanson and Vahlne proposed an international enterprise network model, which indicated that the process of internationalization of companies is a cycle of using knowledge, resources to establish, develop, maintain and end the process of network relationships [9]. Johanson and Mattsson, Coviello and McAuley, Dunning think there are two approaches for SMEs to strengthen network abilities and achieve internationalization: one is to establish new social connections and build strategic alliances by utilizing the internal network resources like interpersonal, technical, economic, legal relationships; The other is to integrate into the existing network relation- 
ships [18] [23]-[25]. Some scholars indicated that SME can take advantage of the existing network relationship or value chain to establish new branch or start an international investment in other countries, which leads to a gradual increase in the enterprise networking capabilities. For instance, some SMEs gain investment channels from their overseas suppliers. Moreover, SMEs can also build their own networks through enterprise clusters to reduce transaction costs, increase productivity, and promote the information flows. The individual interactions strengthen abilities to integrate resources, enhance industrial competitiveness, promote industrial upgrading and boost innovation.

\subsection{Social Capital Theory}

Social capital theory, on the other hand, indicated that social capital is the formation of network link composed by social resources and relations, which has a significant impact on the embedded economic activities [26]. Scholar Chow thinks that social capital could lower transaction cost and operating risks while obtaining information and resources, he divides social capital into three dimensions, including structure, relationships and embedded cognitive social capital [27]. Karagozoglu and Lindell argue that social capital often provides enterprises with critical resources and information. The opportunities and decisions of SME internationalization are related to social capital, SMEs can take advantage of the international development of social capital, and promote the formation of international market experience and knowledge, in order to select the appropriate market entry mode, timing and development model [28].

\subsection{Resource-Based View}

Some scholars explain the motivation of SME FDI with the Resource-based View in Enterprise Management Theory [29]. RBV indicates that the core competitiveness of enterprises is the tangible and intangible resources. They are uncertain, complicated and inimitable but sometimes benefit SME's entry to international market [30]. According to RBV, there are four types of resources that determine SMEs' entry to international market: general human capital resources, the principal founder's management know-how, the principal founder's specific industry know-how, and a principal founder's ability to obtain financial resources that can act as a buffer against random shocks [31]. In comparison to large enterprises, SMEs have advantages in entrepreneur experience, cost, adaptability, learning speed and innovation capacity [32].

Based on the Resource-based View, some scholars use knowledge resources to build a more comprehensive model to explain enterprises' development. Knowledge resources are important comparative advantages which enable SMEs to start internationalization quickly [33], and SMEs are largely dependent on knowledge resources to develop new products, services and international markets [34]. Mejriand Umemoto proposed a knowledgebased model to explain SMEs' involvement in internationalization, which included the following "knowledge factors": the market knowledge and the experiential knowledge composed of network knowledge, cultural knowledge, and entrepreneurial knowledge [35].

\subsection{Global Value Chains and Global Production Network Theory}

Kaplinsky and Readman indicate that SMEs need to go through various processes and standards to join the global value chain, which requires a high fixed cost [36]. However, SMEs still participate in global value chains through a variety of flexible and efficient ways like cooperating with downstream enterprises. Under most circumstances, SMEs get involved in global value chains through joining industrial clusters [37]. Giuliani, Pietrobelli believe that the competitive difference between SMEs originates from their abilities to "upgrade" and "improve", and this competitiveness is often manifested in the ability to innovate or increase the added value of products [38].

Kaplinsky and Readman divide the SMEs in global value chain into two types: buyer-driven chain and producer-driven chain [36]. In buyer-driven chain, SME can conduct FDI through corporation with local enterprises or build transactional corporations; in producer-driven chain, SMEs can join industrial clusters or vertical value chain to achieve mutual cooperation and improve collective efficiency, which can effectively overcome the shortcomings of scale, capital and so on. With the accumulation of international experience, most SMEs' role have gradually transferred from low value-added production processes (such as OEM, OEA) to high valueadded, knowledge-intensive and high return rate of ODM (original design manufacturer) or OBM (Original Brand manufacturers). 


\section{Empirical Analysis of FDI on SMEs}

\subsection{Analysis about Basic Situation}

Buckley, Berkova, Buckley and Newbould summarize FDI scale, orientation, and industry and product characteristics by UK SMEs [39] [40]; Based on the findings of regional classification analysis, Fujita summed up the patterns and trends of SMEs FDI in multiple countries, including investment location, industry choices and so on [41]. His findings include the following statements: SMEs are more focused on investing in developed countries, while investment in developing countries is relatively less; Southeast Asia is a major host country for SMEs; SME's investment range is wide, but most concentrated in electronics, chemicals, textiles, services, and non-equity investments. Óladóttir investigates the FDI motivation, location, mode and trend of NASDAQ-listed SMEs in Iceland, then draw the conclusion that most overseas investment by SMEs are due to the limited local market and the attraction from potential markets, and they often chose larger enterprises as investments [42].

\subsection{Analysis about Driven Factors}

Kuo and Li use risk model to analyze internal factors ( $\mathrm{R} \& \mathrm{D}$ intensives, firm sizes, export ratios and capital intensives) and external factors (resource foundation, relationship network, following markets and strategic considerations) [43]; And conclude that SMEs with a lower degree of capital intensities, a larger firm size, a higher export rations and a larger level of R \& D intensities will have a greater intention to undergo FDI. Hollensteinuses multi-log it model to testify each series of factors in OLI paradigm that affecting FDI on SMEs [14]. He discovers that ownership advantages (O-advantage) are the main driving factors of SMEs' internationalization; location advantages (L-advantage) contribute the FDI of smaller enterprises more obviously; the role of internalization advantages (I-advantage) is not clear.

\subsection{Analysis about Investment Decision-Making}

Urata and Kawai, Jaklič and Svetličič, Wilson use logit model to analyze the barriers of SMEs' FDI from home and host countries [44]-[46]. When making investment decisions, SMEs are more sensitive than large enterprises in the host country's environmental factors, the host country needs to upgrade the hardware (infrastructure) and software (legal policy) both to attract investment from SMEs; Cheng and Yu conduct correlation analysis by questionnaire, then analyze the internationalization decision-making process with the changing institution and external pressure, which is sensitive to the changes of institutional environment from home country [47]. Johnson and Arya use questionnaire and CMV (Common Method Variance) to study the global integration strategies of Taiwanese SMEs in IT industry [48]. They find the negative relationship between competitive actions and business unit integration. Wei and Christodoulou study the decisive factors during SMEs' foreign investment decision-making process, including human resources, ownership network, the host government and information collection [49]. They believe that FDI is a gradual process of learning, SMEs should gradually accumulate experience during FDI decision-making process.

\subsection{Analysis about Location Decision}

Fujita analyzes the main factors of the host country to attract FDI of SMEs in Japan [41]; Chen uses multivariate analysis of variance to study the FDI location decisions of SMEs in Taiwan, find that Taiwanese companies are keen to establish external network connection instead of internal network [50]. When making location decisions, SMEs are more sensitive to networks than large enterprises.

$\mathrm{Li}$ and $\mathrm{Hu}$ study the relationship between the regional technical efficiency and Taiwan SME FDI location through theoretical model and multiple factor analysis [51]. They find that Taiwanese SMEs with higher technical efficiency are more likely to conduct FDI in China mainland. In other countries, however, the relation between technical efficiency and FDI location is not significant. Dhungana analyzes the SME development in Asia region. Compared to large enterprises, SMEs have better flexibility and adaptability, faster decision-making speed and closer customer relationships, their labor-intensive technology is more conducive to explore other community markets in developing countries [52].

\subsection{Analysis about Financing Constraints}

De Maeseneire and Claeys analyze the reasons and forms of financial constraints about Belgian SMEs conduct- 
ing FDI [53]. They think financial constraints would not only restrict the international development of SMEs, but also affect the development of home country and host country; Bannò, Piscitellouse two-step treatment effect mode, comparing the features and financing methods of the firms that benefited from public support with a group of firms that also internationalized their activity in the same period but without any incentive [54]. They find that the public support and incentive play a more significant role on SMEs with internationalization experience, especially the smaller and younger ones.

\subsection{Analysis about Performance}

Beamish and Lee used multiple regression analysis to study the characteristics and performance of SMEs in Korea branches in emerging markets and have following findings: compared to establish a wholly owned subsidiary, the Korean SMEs are more inclined to adopt a joint approach to establish a branch, and the control degree by parent company has a decisive impact on their performance [55]; Cheng and Yu use ANOVA (Analysis of Variance) to study the overseas branches of Taiwanese SMEs from the perspective of institutional theory [56]. The results show that their operative activities are restricted to parent companies. Musteen, Francis study how the international network influence the international speed and performance of SMEs in Czech, they find that SMEs with diverse networks in different regions would have better internationalization performance, over-reliance on interpersonal networks will discourage international new ventures investments [57]. Vachani analyzes the problems that the foreign affiliates in Japanese SMEs encounter during internationalization, and indicates the importance of institutional issues (institutional distance, legality, etc.) as well as factors that FDI theory suggests are related to multinationals, such as industry concentration and high technology [58]. Lu and Beamish analyze the relationship between FDI of Japanese SMEs and their performance, they use ROA (Return on Assets) and ROS (Return on Assets) as measurements respectively [59]. The results show that FDI is positively correlated to business growth, but a U-shaped relationship with profit margin. Moreover, export activities have a positive effect in regulating the growth of FDI in relation to the business.

\section{Conclusion}

The above literature review shows that the present study of SMEs FDI has the following deficiencies: 1) lack of the analysis to explain SMEs' involvement in FDI from the perspective of the evolution of the international division; 2) lack of the analysis about SMEs internationalization pattern from perspective of heterogeneity; 3) lack of the social effects analysis of home and host countries as well as analysis of the similarities and differences with the large multinationals; 4) lack of the analysis about the characteristics of industry that SMEs conduct FDI; 5) lack of the analysis about SMEs in services while the service sector SMEs often have a higher internationalization degree than manufacturing.

\section{References}

[1] Hymer, S. (1976) The International Operations of National Firms: A Study of Direct Foreign Investment. MIT Press, Cambridge, MA, Vol. 14.

[2] Vernon, R. (1966) International Investment and International Trade in the Product Cycle.

[3] Kojima, K. (1975) International Trade and Foreign Investment: Substitutes or Complements. Hitotsubashi Journal of Economics, 16, 1-12.

[4] Buckley, P.J. and Casson, M. (1976) The Future of the Multinational Enterprise. Macmillan, London, Vol. 1.

[5] Dunning, J.H. (1979) Explaining Changing Patterns of International Production: In Defence of the Eclectic Theory. Oxford Bulletin of Economics and Statistics, 41, 269-295. http://dx.doi.org/10.1111/j.1468-0084.1979.mp41004003.x

[6] Dunning, J.H. (1980) Toward an Eclectic Theory of International Production: Some Empirical Tests. Journal of International Business Studies, 11, 9-31. http://dx.doi.org/10.1057/palgrave.jibs.8490593

[7] Caves, R.E. (1974) Multinational Firms, Competition, and Productivity in Host-Country Markets. Economica, 41, 176193. http://dx.doi.org/10.2307/2553765

[8] Johanson, J. and Wiedersheim-Paul, F. (1975) The Internationalization of the Firm—Four Swedish Cases 1. Journal of Management Studies, 12, 305-323. http://dx.doi.org/10.1111/j.1467-6486.1975.tb00514.x

[9] Johanson, J. and Vahlne, J.-E. (1977) The Internationalization Process of the Firm-A Model of Knowledge Development and Increasing Foreign Market Commitments. Journal of International Business Studies, 8, 23-32. 
http://dx.doi.org/10.1057/palgrave.jibs.8490676

[10] Knight, G. (1996) Born Global. Wiley International Encyclopedia of Marketing.

[11] McDougall, P.P. and Oviatt, B. (1994) Toward a Theory of International New Ventures. Journal of International Business Studies, 25, 45-64. http://dx.doi.org/10.1057/palgrave.jibs.8490193

[12] Buckley, P.J. (1989) Foreign Direct Investment by Small and Medium Sized Enterprises: The Theoretical Background. Small Business Economics, 1, 89-100. http://dx.doi.org/10.1007/BF00398627

[13] Liesch, P.W. and Knight, G.A. (1999) Information Internalization and Hurdle Rates in Small and Medium Enterprise Internationalization. Journal of International Business Studies, 30, 383-394. http://dx.doi.org/10.1057/palgrave.jibs.8490075

[14] Hollenstein, H. (2005) Determinants of International Activities: Are SMEs Different? Small Business Economics, 24, 431-450. http://dx.doi.org/10.1007/s11187-005-6455-x

[15] Wells, L.T. (1983) Third World Multinationals: The Rise of Foreign Investments from Developing Countries. MIT Press, Cambridge, MA.

[16] Rennie, M.W. (1993) Global Competitiveness: Born Global. McKinsey Quarterly, 4, 45-52.

[17] Hollensen, S. (2007) Global Marketing: A Decision-Oriented Approach. Pearson Education, Upper Saddle River.

[18] McDougall, P.P. and Oviatt, B.M. (2000) International Entrepreneurship: The Intersection of Two Research Paths. Academy of Management Journal, 43, 902-906. http://dx.doi.org/10.2307/1556418

[19] Knight, G. (2000) Entrepreneurship and Marketing Strategy: The SME under Globalization. Journal of International Marketing, 8, 12-32. http://dx.doi.org/10.1509/jimk.8.2.12.19620

[20] Bilkey, W.J. (1978) An Attempted Integration of the Literature on the Export Behavior of Firms. Journal of International Business Studies, 9, 33-46. http://dx.doi.org/10.1057/palgrave.jibs.8490649

[21] Johansson, J.K. and Nonaka, I. (1983) Japanese Export Marketing: Structures, Strategies, Counterstrategies. International Marketing Review, 1, 12-25. http://dx.doi.org/10.1108/eb008248

[22] Yip, G.S., Biscarri, J.G. and Monti, J.A. (2000) The Role of the Internationalization Process in the Performance of Newly Internationalizing Firms. Journal of International Marketing, 8, 10-35. http://dx.doi.org/10.1509/jimk.8.3.10.19635

[23] Johanson, J. and Mattsson, L.-G. (1994) The Markets-As-Networks Tradition in Sweden. Springer, Berlin.

[24] Coviello, N.E. and McAuley, A. (1999) Internationalisation and the Smaller Firm: A Review of Contemporary Empirical Research. MIR: Management International Review, 39, 223-256.

[25] Dunning, J.H. (2002) Regions, Globalization, and the Knowledge-Based Economy. Oxford University Press, Oxford. http://dx.doi.org/10.1093/0199250014.001.0001

[26] Adler, P.S. and Kwon, S.-W. (2002) Social Capital: Prospects for a New Concept. Academy of Management Review, 27, 17-40.

[27] Chow, X. (2006) A Literature Review on SME Internationalization Strategy: Based on the Theory of Social Capital. Foreign Economics and Management, 2006, 17-22.

[28] Karagozoglu, N. and Lindell, M. (1998) Internationalization of Small and Medium-Sized Technology-Based Firms: An Exploratory Study. Journal of Small Business Management, 36, 44-59.

[29] Hitt, M.A., Bierman, L., Uhlenbruck, K. and Shimizu, K. (2006) The Importance of Resources in the Internationalization of Professional Service Firms: The Good, the Bad, and the Ugly. Academy of Management Journal, 49, 1137-1157. http://dx.doi.org/10.5465/AMJ.2006.23478217

[30] Bloodgood, J.M., Sapienza, H.J. and Almeida, J.G. (1996) The Internationalization of New High-Potential US Ventures: Antecedents and Outcomes. Entrepreneurship Theory and Practice, 20, 61-76.

[31] Westhead, P., Wright, M. and Ucbasaran, D. (2001) The Internationalization of New and Small Firms: A ResourceBased View. Journal of Business Venturing, 16, 333-358. http://dx.doi.org/10.1016/S0883-9026(99)00063-4

[32] Ruzzier, M., Hisrich, R.D. and Antoncic, B. (2006) SME Internationalization Research: Past, Present, and Future. Journal of Small Business and Enterprise Development, 13, 476-497. http://dx.doi.org/10.1108/14626000610705705

[33] Gassmann, O. and Keupp, M.M. (2007) The Competitive Advantage of Early and Rapidly Internationalising SMEs in the Biotechnology Industry: A Knowledge-Based View. Journal of World Business, 42, 350-366. http://dx.doi.org/10.1016/j.jwb.2007.04.006

[34] Zahra, S.A., Neubaum, D.O. and Naldi, L. (2007) The Effects of Ownership and Governance on SMEs’ International Knowledge-Based Resources. Small Business Economics, 29, 309-327. http://dx.doi.org/10.1007/s11187-006-9025-y 
[35] Mejri, K. and Umemoto, K. (2010) Small- and Medium-Sized Enterprise Internationalization: Towards the Knowledge-Based Model. Journal of International Entrepreneurship, 8, 156-167. http://dx.doi.org/10.1007/s10843-010-0058-6

[36] Kaplinsky, R. and Readman, J. (2001) Integrating SMEs in Global Value Chains: Towards Partnership for Development. Unido, Vienna.

[37] Pietrobelli, C. and Rabellotti, R. (2004) Upgrading in Clusters and Value Chains in Latin America: The Role of Policies. Inter-American Development Bank, Washington DC.

[38] Giuliani, E., Pietrobelli, C. and Rabellotti, R. (2005) Upgrading in Global Value Chains: Lessons from Latin American Clusters. World Development, 33, 549-573. http://dx.doi.org/10.1016/j.worlddev.2005.01.002

[39] Buckley, P.J., Berkova, Z. and Newbould, G.D. (1983) Direct Investment in the UK by Smaller European Firms. Macmillan, London.

[40] Buckley, P.J., Newbould, G.D. and Thurwell, J.C. (1988) Foreign Direct Investment by Smaller UK Firms: The Success and Failure of First-Time Investors Abroad. Macmillan, London.

[41] Fujita, M. (1995) Small and Medium-Sized Transnational Corporations: Trends and Patterns of Foreign Direct Investment. Small Business Economics, 7, 183-204. http://dx.doi.org/10.1007/BF01135364

[42] Óladóttir, Á.D. (2009) Internationalization from a Small Domestic Base: An Empirical Analysis of Foreign Direct Investments of Icelandic Firms. Management International Review, 49, 61-80. http://dx.doi.org/10.1007/s11575-008-0125-6

[43] Kuo, H.-C. and Li, Y. (2003) A Dynamic Decision Model of SMEs’ FDI. Small Business Economics, 20, $219-231$. http://dx.doi.org/10.1023/A:1022819206036

[44] Urata, S. and Kawai, H. (2000) The Determinants of the Location of Foreign Direct Investment by Japanese Small and Medium-Sized Enterprises. Small Business Economics, 15, 79-103. http://dx.doi.org/10.1023/A:1008173912813

[45] Jaklič, A. and Svetličič, M. (2003) Enhanced Transition through Outward Internationalization: Outward FDI by Slovenian Firms. Ashgate Publishing Ltd., Farnham.

[46] Wilson, K. (2006) Encouraging the Internationalisation of SMEs. OECD Papers, 6, 43-66.

[47] Cheng, H.-L. and Yu, C.M.J. (2008) Institutional Pressures and Initiation of Internationalization: Evidence from Taiwanese Small- and Medium-Sized Enterprises. International Business Review, 17, 331-348. http://dx.doi.org/10.1016/j.ibusrev.2008.01.006

[48] Johnson, J.H., Arya, B. and Mirchandani, D.A. (2013) Global Integration Strategies of Small and Medium Multinationals: Evidence from Taiwan. Journal of World Business, 48, 47-57. http://dx.doi.org/10.1016/j.jwb.2012.06.006

[49] Wei, H.-C. and Christodoulou, C. (1997) An Examination of Strategic Foreign Direct Investment Decision Processes: The Case of Taiwanese Manufacturing SMEs. Management Decision, 35, 619-630. http://dx.doi.org/10.1108/00251749710176145

[50] Chen, H. and Chen, T.-J. (1998) Network Linkages and Location Choice in Foreign Direct Investment. Journal of International Business Studies, 29, 445-467. http://dx.doi.org/10.1057/palgrave.jibs.8490002

[51] Li, Y. and Hu, J.-L. (2002) Technical Efficiency and Location Choice of Small and Medium-Sized Enterprises. Small Business Economics, 19, 1-12. http://dx.doi.org/10.1023/A:1015770220239

[52] Dhungana, B.P. (2003) Strengthening the Competitiveness of Small and Medium Enterprises in the Globalization Process: Prospects and Challenges. Investment Promotion and Enterprise Development Bulletin for Asia and the Pacific, 1, 1-32.

[53] De Maeseneire, W. and Claeys, T. (2012) SMEs, Foreign Direct Investment and Financial Constraints: The Case of Belgium. International Business Review, 21, 408-424. http://dx.doi.org/10.1016/j.ibusrev.2011.03.004

[54] Bannò, M., Piscitello, L. and Amorim Varum, C. (2014) The Impact of Public Support on SMEs' Outward FDI: Evidence from Italy. Journal of Small Business Management, 52, 22-38. http://dx.doi.org/10.1111/jsbm.12029

[55] Beamish, P.W. and Lee, C. (2003) The Characteristics and Performance of Affiliates of Small and Medium-Size Multinational Enterprises in an Emerging Market. Journal of International Entrepreneurship, 1, 121-134. http://dx.doi.org/10.1023/A:1023223424789

[56] Cheng, H.-L. and Yu, C.-M. (2012) Adoption of Practices by Subsidiaries and Institutional Interaction within Internationalised Small-and Medium-Sized Enterprises. Management International Review, 52, 81-105. http://dx.doi.org/10.1007/s11575-011-0117-9

[57] Musteen, M., Francis, J. and Datta, D.K. (2010) The Influence of International Networks on Internationalization Speed and Performance: A Study of Czech SMEs. Journal of World Business, 45, 197-205. http://dx.doi.org/10.1016/j.jwb.2009.12.003 
[58] Vachani, S. (2005) Problems of Foreign Subsidiaries of SMEs Compared with Large Companies. International Business Review, 14, 415-439. http://dx.doi.org/10.1016/j.ibusrev.2005.03.002

[59] Lu, J.W. and Beamish, P.W. (2006) SME Internationalization and Performance: Growth vs. Profitability. Journal of International Entrepreneurship, 4, 27-48. http://dx.doi.org/10.1007/s10843-006-8000-7 
Scientific Research Publishing (SCIRP) is one of the largest Open Access journal publishers. It is currently publishing more than 200 open access, online, peer-reviewed journals covering a wide range of academic disciplines. SCIRP serves the worldwide academic communities and contributes to the progress and application of science with its publication.

Other selected journals from SCIRP are listed as below. Submit your manuscript to us via either submit@scirp.org or Online Submission Portal.
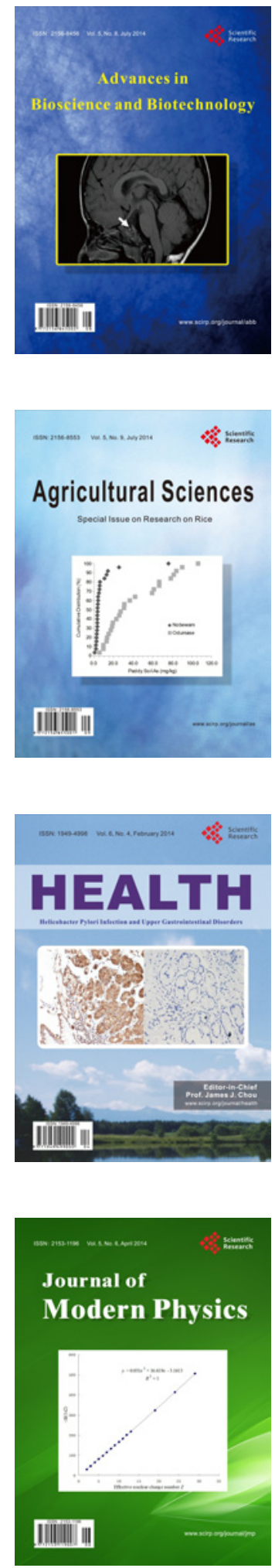
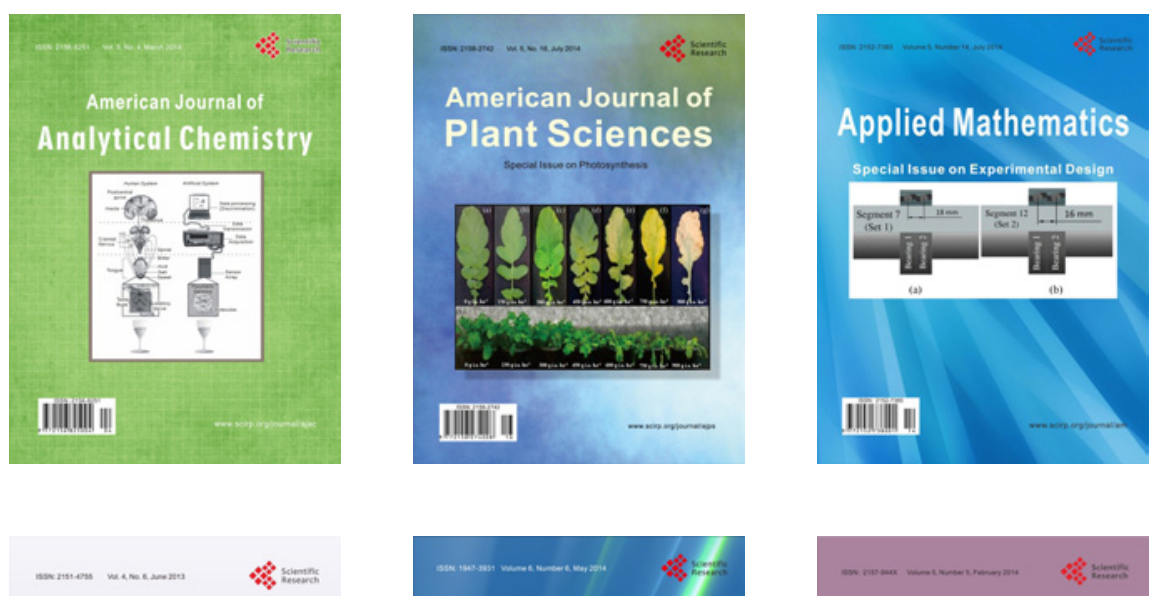

Creative Education
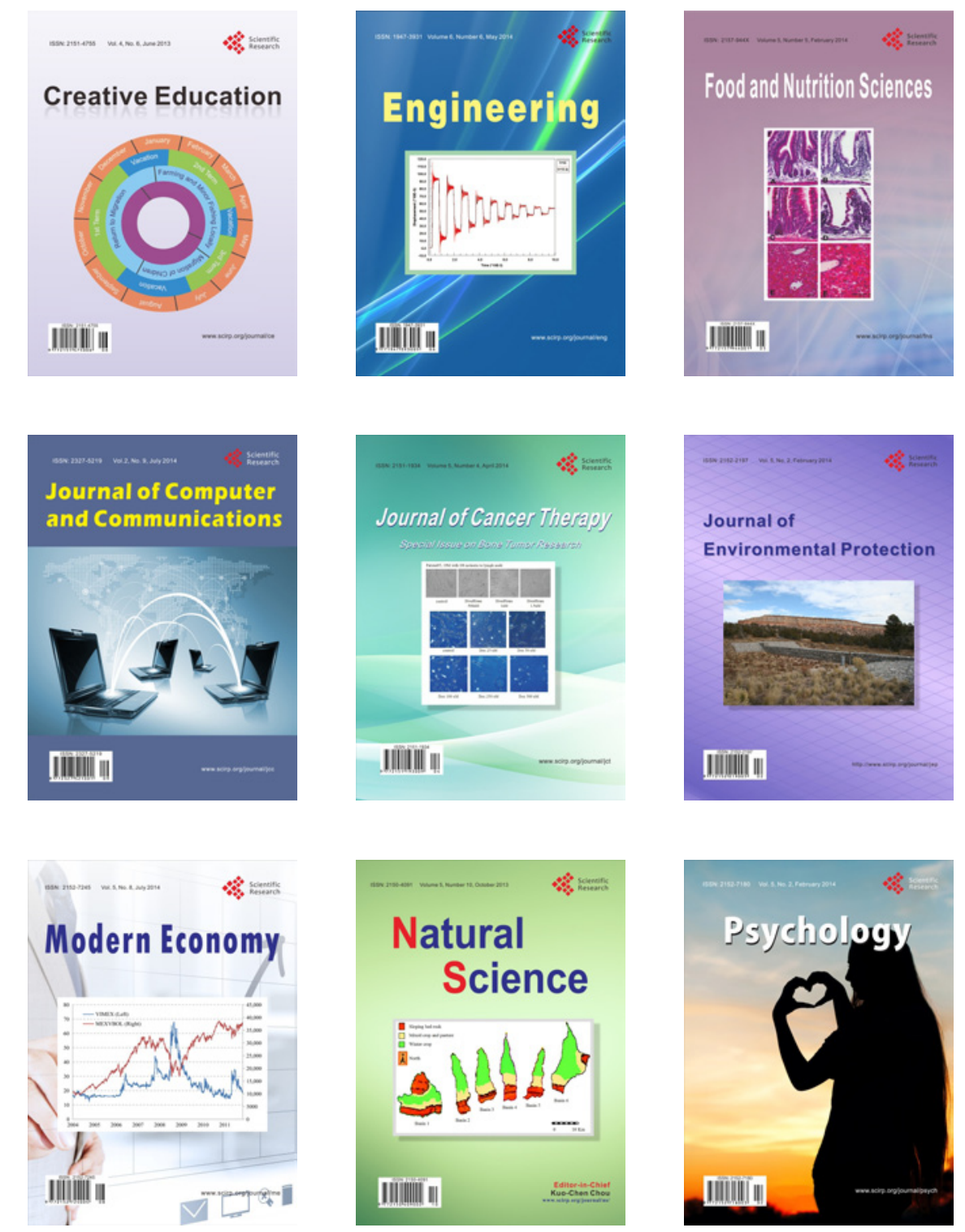